\title{
ADMINISTRATIVE SERVICES PROVISION IN LICENSING SYSTEM OF THE NATIONAL POLICE OF UKRAINE: GENESIS AND POSSIBILITIES OF FOREIGN EXPERIENCE USE
}

Fomenko A. Ye.

\section{INTRODUCTION}

Law enforcement by preventing and eliminating of offenses, as well as bringing guilty persons to justice, is one of the primary tasks of the modern legal state. This is because the protection of law and order along with the national security is a guarantee of respect for citizens' legal rights and interests. In the exercise of this state function, a significant role is played by public authorities, which are empowered with this purpose by the controlling and supervisory powers.

Of particular importance here are the permit functions of law enforcement agencies aimed at monitoring the observance by individuals and legal entities of special rules and procedures for the storage and use of weapons, special personal protective equipment and active defense, ammunition, explosives, other objects, materials and substances to which the licensing system is applied.

In such circumstances, the priority activity of the government is the establishment of an effective mechanism for the exercise of permit powers in relation to such objects of the licensing system by the competent authorities.

In particular, at the present stage of the state establishment in Ukraine, an important element of such a mechanism should include the activities of bodies and units of the National Police of Ukraine, which provide administrative services to citizens. Thus, the special place of this central body of state power in the licensing system of the country is justified by the fact that the creation of a new service today, represented by the National Police, is one of the conditions for the formation of a democratic, legal and social Ukrainian state.

Along with this, it is necessary to pay attention to the international aspect of solving the problem of a new police force creation, which will provide the Ukrainian citizens with administrative services, including 
the field of permission. In particular, reformation of the system of the Ministry of Internal Affairs of Ukraine and improvement of its organizational foundations and functioning principles is carried out in line with global civilization processes, which not only lead to external changes in the mechanism of law enforcement activity, but also leave a significant imprint on the ideological basis of the society existence, transform the idea of political power, its nature and limits of implementation, the state power and civil society power ratio.

\section{Genesis of administrative services provided by the National Police of Ukraine}

Administrative services provided by the National Police of Ukraine as a subject of scientific research in Ukraine have emerged not so long ago. This is due to a number of objective circumstances. In particular, in the science of the Soviet era, such studies were lacking at all, based on the very approach to understanding the purpose and functioning of law enforcement agencies. For example, in the Soviet period, the militia (from the Latin "militia"- people's army) was regarded as a workers 'and peasants' voluntary formation, which was formed and operated to protect the interests of the state. In Ukraine the workers 'and peasants' militia was established by a decree of the Council of People's Commissars of the Ukrainian Socialist Soviet Republic dated February 9, 1919, which stipulated that the main task of the militia was to protect the revolutionary order, as well as to combat "criminal elements which were the result of capitalism". For many years, the police were perceived as a purely state body that represented exclusively the interests of the state and were, so to say, "away from" the community needs.

Therefore, taking into account such an approach to the activities of Soviet-era law-enforcement bodies, there was no scientific development in the provision of these services to the citizens, unlike in foreign studies. The police functioned abroad (from the Latin politia government), was defined as a highly qualified, professional, armed body of legal order, which was designated by the state to protect the rights and safety of citizens and their property. It should be noted that

earlier the police were also perceived as militarized units protecting the interests of the state, but in the 1960s practically all Western European countries have proclaimed a course for large-scale reform of law enforcement agencies. As a result, the police turned into an authority 
whose main function is to provide services to the public, protect rights and freedoms of the man and the citizen ${ }^{1}$. Such reform was based on the elaborations of public services, where the state through the authorities acts in the interests of the citizen and serves for their benefit, and not vice versa, as it was in the USSR.

The achievements of the Soviet era can be used to define the development of scientists in the study of the general administrative activity of the police, in the context of which it is possible to identify those directions and actions that were related to the area of the internal affairs functioning as a service.

The first to address this issue was L.M. Rozin, who defined the police administrative activity as follows: this activity focuses on the administrative supervision, the implementation of passport and permit systems, ensuring the safety of traffic and pedestrians ${ }^{2}$. In this definition, the scientist defines the areas of administrative activity, but it does not take into account the external component of the operation of the police, namely, public order protection.

Another researcher, M.I. Yeropkin, in his scientific work "Management in the field of protection of public order" determined that the police administrative activity comprises the organization and practical implementation of its bodies and in close connection with a wide range of public functions of public order, law, rights and interests of citizens by administrative legal means and in the administrative legal forms ${ }^{3}$. In our opinion, this definition is quite abstract, in which there is no indication of the specific content and forms of such police activity. In addition, the definition does not include such important areas of administrative activity as the implementation of the permit system and road safety.

The most accurate and comprehensive concept of administrative activity was formulated by F.Yu. Kolontayevskiy. According to this scholar, the police administrative activity should be understood as executive-administrative activity, which focuses on the provision of

1 Ратушняк В. Перспективні шляхи удосконалення управління міліцією громадської безпеки в Україні. Вісник Київського начіонального університету імені Тараса Шевченка. Серія: Юридичні науки. 2013. № 2 (96). С. 12-16. С. 14 C. 147.

${ }^{2}$ Советское административное право / под ред. А. Е. Лунева. М. : ВЮЗИ, 1960.

${ }^{3}$ Еропкин М. И. Управление в области охраны общественного порядка. М. : Юр. лит., 1965. С. 83-84. 
foreign service, ensuring the safety of traffic and pedestrians, the implementation of passport and permitting systems and directed through various preventive measures, administrative supervision, issuance of management acts, conclusion of contracts on protection of objects, implementation of other legally significant actions and logistical actions in public order maintenance, protection of national interests and citizens' rights from criminal and other anti-social attacks ${ }^{4}$. In our opinion, for that period of time this definition is fully reflected the content and forms of police administrative activity, as well as the area of legal relations of its implementation. Such provisions formed the basis for further scientific development of this issue and research, the subject of which was the provision of administrative services of law enforcement agencies in the post-Soviet period in Ukraine before the formation of the National Police.

Thus, in the early 1990-s, due to the declaration of independence of Ukraine, the development of its statehood, and at the same time the formation of a new state apparatus, new approaches to organizing the functioning of state power in general and law enforcement agencies, in particular, began to emerge. In this context, due to the fact that the internal affairs bodies referred to the executive branch of the government, it should be considered how the concept of "administrative" or "administrative services" in the activity of public authorities began to be fixed at the legislative level.

The Concept of Administrative Reform of 1998 was one of the first acts of domestic legislation that referred to the concept of management services. In this Concept, the primary task is to introduce a new ideology of functioning of state executive bodies and local self-government bodies as an activity to ensure the implementation of citizens' rights and freedoms and provide them with quality management services ${ }^{5}$.

The next step of the legislators in this direction was the measures to implement the main areas of competition policy for 2002-2004, approved by the Decree of the President of Ukraine of November 19,

4 Колонтаевский Ф. Е. Обеспечение социалистической законности в административной деятельности милиции : автореф. дис.. ...канд. юрид. наук : 12.00.07. М., 1970. С. 9.

5 Про заходи щодо впровадження Концепції адміністративної реформи в Україні : Указ Президента України від 22 липня 1998 р. № 810. Офіційиний вісник Украӥни. 1999. № 21. С. 32. 
2001 No. 1097, which provided for optimization of the economic activity of executive bodies and local self-government bodies ${ }^{6}$.

However, for the first time at the state level, the issue of administrative services was mentioned in the Concept of Development of the System of Provision of Administrative Services by Executive Bodies in 2006. Though, only in 2008 some of its provisions began to be put into practice (the result of which is Government Decree No. 737 "On the streamlining of administrative services" of July 17, 20097), which were primarily concerned with the task of eliminating enterprises, institutions, organizations providing "public and administrative services", or deprive them of their respective powers. The Temporary Procedure for the Provision of Administrative Services, approved by the aforementioned Decree, also defined certain limits for the provision of administrative services; the procedure for directing funds to the budget received for administrative services; requirements for the provision of information on administrative services and some other requirements for entities providing administrative services ${ }^{8}$.

The final legislative act governing public relations related to the provision of administrative services by state authorities and local selfgovernment is the Parliament-approved Law on Administrative Services of September 6, 2012. Its main positive aspects can be considered:

- the responsibility of local governments and district state administrations to set up administrative service centers (ASCs);

- a legal ban on requiring documents and information that are already in the possession of administrative service providers or which they can obtain independently;

- streamlining internal procedures for the provision of administrative services (through the introduction of technological service cards) and the provision of convenient information for service

6 Про основні напрямки конкурентної політики на 2002-2004 pp. : Указ Президента України від 19 листопада 2001 р. № 1097/2001. Офіuійний вісник України. 2001. № 47. С. 14. Ст. 2056.

7 Про заходи щодо упорядкування адміністративних послуг : Постанова Кабінету Міністрів України від 17 липня 2009 p. № 737. URL : http://zakon5.rada.gov.ua/laws/show/737-2009-\%D0\%BF.

8 Тимощук В. П. Адміністративні послуги: проблеми теорії, законодавства i практики в Україні. Адміністративне право і процес. 2014. № 3(9). С.104-120. URL: http://applaw.knu.ua/index.php/arkhiv-nomeriv/3-9-2014-jubilee/item/383-administratyvniposluhy-problemy-teoriyi-zakonodavstva-i-praktyky-v-ukrayini-tymoshchuk-v-p. 
users (through the obligation to provide wide information and the introduction of administrative service information cards);

- introduction of a unified concept of "administrative fee" as a single payment for paid administrative services;

- guaranteeing a minimum number of hours for reception of applicants ${ }^{9}$.

According to Art. 5 of the above Law, the administrative services are as follows: issuance of licenses, permits and other permit documents: for activities of a certain type, for certain works and services, for certain objects (land, house, building, their complexes, premises, equipment and mechanisms to be put into operation or designed, others) and operations with them; registration of: facts, subjects, rights, objects, including legalization of subjects and acts (documents); accreditation, attestation and certification, nostrification and verification; other activities that result in the granting or confirmation of a certain legal status to the interested individuals and legal entities, as well as to objects owned, or used by them.

According to the Law of Ukraine "On Administrative Services", the subject of administrative service provision is the executive authority, other state body, local self-government body, their officials authorized under the law to provide administrative services ${ }^{10}$.

The Ministry of Internal Affairs of Ukraine can certainly be attributed to public authorities, which, under current national law, have the power to provide administrative services. In particular, the analysis of the Regulation on the Ministry of Internal Affairs, approved by Presidential Decree No. 383 of April 6, 2011, indicates that there is a substantial amount of work related to the issuance of permits, registration of entities, rights, objects, etc. At the same time, the Regulation emphasizes that such work must be carried out either within the competence or within the powers of the relevant units of the Ministry of Internal Affairs of Ukraine ${ }^{11}$.

9 Тимощук В. П. Адміністративні послуги: проблеми теорії, законодавства і практики в Україні . Адміністративне право і процес. 2014. № 3(9). С. 107-108. URL: http://applaw.knu.ua/index.php/arkhiv-nomeriv/3-9-2014-jubilee/item/383-administratyvniposluhy-problemy-teoriyi-zakonodavstva-i-praktyky-v-ukrayini-tymoshchuk-v-p.

10 Про адміністративні послуги : Закон України від 6 вересня 2012 р. № 5203VI. Відомості Верховної Ради Украӥни. 2013. № 32. Ст. 409.

11 Про затвердження Положення про Міністерство внутрішніх справ України : Указ Президента України від 06 квітня 2011 p. № 383 . URL : http://zakon3.rada.gov.ua/laws/show/383/2011. 
At the same time, activities related to the provision of services for the issuance of permits, licenses, certificates, etc. by public authorities, in particular law enforcement agencies, were in fact carried out prior to the emergence of normative consolidation of this type of activity as administrative services. The respective powers of law enforcement agencies in accordance with the tasks assigned to them were enshrined at the level of decrees of the Cabinet of Ministers of Ukraine, as well as interagency or departmental orders registered with the Ministry of Justice of Ukraine. An example is the following normative acts: Decree of the Cabinet of Ministers of Ukraine of December 25, 2002 No. 1952 "On Approval of the List of Paid Services that can be Provided by Customs Bodies", as amended in accordance with the Decree of the Cabinet of Ministers of Ukraine No. 92 of January 18, 2003 p .; Decree of the Cabinet of Ministers of Ukraine of June 4, 2007 No. 795 "On Approving the List of Paid Services that may be Provided by Bodies and Subdivisions of the Ministry of Internal Affairs", as amended in accordance with the Decrees of the Cabinet of Ministers of Ukraine of January 28, 2009. No. 65 and from July 1, 2009 No. 724; Decree of the Cabinet of Ministers of Ukraine of November 14, 2000 No. 1698 "On Approval of the List of Licensing Bodies" in the version of March 25, 2010, based on the Decree of the Cabinet of Ministers of Ukraine of March 17, 2010, No. 275.

When defining the emergence of management services in legislative acts, it is necessary to point out the ambiguity of definitions in the normative practice of the concepts of state, public, administrative services, as well as the use of the latter as synonyms. At the same time, the situation where some legal scholars questioned the very possibility of using the category of "services" for the activities of authorities exercising powers, obliged scholars to study the problems of administrative services, including those provided by law enforcement agencies. The importance of defining the concept in the applied aspect was substantiated by the presence of the problem of scientific research of the phenomenon and the need to develop a strategy and tactics for improving the public effectiveness of public authorities' activity, including law enforcement agencies, while providing services ${ }^{12}$.

12 Шапоренко М. М. Адміністративні послуги правоохоронних органів: до проблеми понятійного апарату. Право і суспільство. 2011. № 5. С. 120 
Therefore, along with the statutory determination of administrative services, among scholars there was the formation of scientific views on the activities of law enforcement agencies in the field of administrative services to the public. It should be noted that in the administrative law science the category of "administrative services of law enforcement agencies" was debatable, which aroused considerable interest among scholars in the field of law. Scientific researches of this category is important for the formation of a modern understanding of such a new legal phenomenon as "police administrative services", since the central executive body, represented by the National Police of Ukraine, arose from the liquidation of the police and performs a large part of the functions previously owned by the this internal affairs body. In this regard, it is considered appropriate to analyze the views of administrative scientists on the definition of "administrative services of law enforcement agencies", which will allow to improve approaches to clarify the nature and content of police service, in particular with regard to the provision of administrative services at the present stage reforming the system of the Ministry of Internal Affairs of Ukraine.

Summarizing the above stated, it should be noted that the political, economic and social renewal of society in the course of a democratic legal state creation has caused the need to bring legal, organizational, structural and other foundations of the functioning of state executive bodies in line with the new conditions of their activity and development ${ }^{13}$. The activity of the police in the provision of administrative services, which, in our opinion, should first of all be directed, first of all, to ensuring the realization of the rights, freedoms and legal interests granted to individuals and legal entities has not become an exception; secondly, the establishment of partnerships between the units of the National Police of Ukraine and the population, which became possible during the transition of the police from punitive, repressive and control activities to servicing and supervision one.

Thus, the creation of the concept of administrative services in the field of jurisprudence provided by the National Police of Ukraine is not aimed at introducing a separate type of administrative and legal relations

13 Іншин М. I. Правове регулювання вивільнення працівників органів внутрішніх справ України : навчально-практичний посібник ; за ред. В. С. Венедиктова. Харків : Ун-т внутр. справ, 2000. С. 74. 
between law enforcement agencies and the individual, but to review the relationship between them, since the supremacy of law is implemented in terms of its content. First and foremost, the changes provide the replacement of the "state domination" ideology in the past into the ideology of "state service" to the interests of man ${ }^{14}$. And such serving will be manifested through the quality of administrative services provided to the citizens by the public authorities in general and the National Police bodies in particular.

\section{Foreign experience in providing administrative services}

Analyzing the foreign countries' experience, in particular the European Union member states in the administrative services provision, it should be noted that it is extremely important for our country, since the Ukrainian state has chosen the European vector of development and is undergoing a radical reform of approaches to the organization of functioning of public authorities, by decentralization of power and creation of civil society. It is therefore important, when carrying out reforms in the administrative services sector, to pay attention to the principles that serve as a common platform for the development of the administrative services system in the European Union, in particular:

- the principle of subsidiarity and proportionality. It requires the governing bodies to make administrative service decisions as closely as possible to consumers, that is, to provide administrative services at local, regional, national or European Union level, where their provision is considered the most effective. Proportionality restricts the actions of the higher authorities only to what is necessary to achieve the policy goals agreed with other levels of government, that is, to ensure the maximum freedom of decision of the participating countries;

- the principle of orientation towards consumers, citizens and enterprises, whose needs are determined by the list and procedure for the administrative services provision. Beneficiaries' needs include: 1) secure and flexible access (personalization of services); 2) multichannel (maximum availability); 3) "single window" (receiving administrative services in one place, even if the service is provided jointly by several bodies); 4) discontinuity (avoiding re-provision of information required

14 Денисюк Д. С. Визначення адміністративної послуги в діяльності органів внутрішніх справ. Актуальні проблеми державного управління. 2008. № 2. С. 405 
to receive services); 5) mutual trust (keeping confidential and private data);

- the principle of public access, that is to say, to create equal opportunities at all levels for all citizens and companies of the European Union countries without any discrimination;

- the principle of security (confidentiality). It means that the authorities must guarantee the privacy of citizens' privacy and the confidentiality of information received from business entities. Considering safety requirements, consumers have the right to control the use of management information collected about them for declared purposes $^{15}$;

- the principle of multilingualism must also be taken into account, since without it it's impossible to ensure the observance of guaranteed rights and freedoms, accessibility, quality, multilateral cooperation in the process of providing administrative services in a multi-ethnic, multilingual environment, which is the EU;

- the principle of administrative simplicity. It provides for simplification of procedures for citizens and businesses to reduce their administrative costs;

- the principle of transparency, which ensures that the process is understandable, as well as the right of recipients to have an idea of the mechanisms for making decisions regarding the provision of appropriate administrative services;

- the principle of sustainability of information. It is implemented in various forms of documentation of procedures and decisions regarding administrative services, i.e. maintaining the integrity, reliability and accuracy of information over a long period of time, taking into account the conditions of security and confidentiality;

- the principle of openness, reflecting the willingness of individuals, businesses and organizations to share experience and aiming to increase participants' knowledge in order to solve priority problems in the field of administrative services;

- the principle of experience exchange. It means that governing bodies should share with other concepts, methods, procedures that have proven themselves well in practice;

${ }^{15}$ Сєніна А. О. Особливості та організаційний досвід надання адміністративних послуг у країнах ЄС. Бізнес Інформ. 2014. № 8. С. 25-33. 
- the principle of adaptability. Its essence is that governing bodies focus efforts on the implementation of administrative services that are able to adapt in a changing socio-economic environment, regardless of the place of their provision and the recipient of services;

- the principle of efficiency and effectiveness. It envisages the creation of an environment that provides administrative services to the maximum number of businesses and citizens with minimal costs (costbenefit optimization), taking into account other principles such as adaptability, simplicity, security, etc. ${ }^{16}$

The use of foreign experience in the organization of work on the provision of administrative services by public authorities also concerns the sphere of operation of law enforcement agencies, and in particular the police. This is due to the fact that overseas reform of state authorities in matters of interaction with citizens occurred along with the reorientation of police bodies from a punitive body to a public service, which should act for the benefit of the population and provide it with appropriate services. Therefore, a new approach to law enforcement is becoming more widespread today as an organization that provides services to the public in the field of law enforcement, including services aimed at protecting citizens from unlawful encroachment.

This position was reflected in a number of national and international documents as early as the 1970s. As outlined in the Code of Conduct for Law Enforcement Officials adopted by the UN General Assembly on December 17, 1979, service to the community is, in particular, to provide services and assistance to members of the community who, for personal, economic, social or other reasons of urgent need for assistance. The partial transformation of law enforcement into a service will significantly improve the efficiency of the work of law enforcement by bringing its professional activity closer to the population, while reducing the repressive measures of influence. The priority should be given to the prevention of offenses, not to the elimination of their harmful consequences ${ }^{17}$.

Considering the possibility of implementing the foreign experience of the service function by the police authorities, it should be noted that the first European Congress on Police Quality Management, held in

${ }^{16}$ Сєніна А. О. Особливості та організаційний досвід надання адміністративних послуг у країнах СС. Бізнес Інформ. 2014. № 8. С. 27.

${ }_{17}$ Суббот А. Застосування в Україні передових світових стандартів організації ефективної діяльності правоохоронних органів. Віче. 2014. № 10. С. 7. 
Munster (Germany) in March 1998, was an indicator of the introduction of the concept of quality management to the field of policing. The Congress identified the main approaches for creation of a new model of police activity and emphasized that, firstly, the police are seen as a body that provides services to the population in a particular territory, and secondly, the police should exist for the citizens, developing for them the system of services ${ }^{18}$.

Police transformations in the countries of Central and Eastern Europe (Germany, Hungary, Poland, Slovenia, Czech Republic, Bulgaria, Balkan countries, Russia) indicates the influence of international principles and standards on the police reform processes, on the sphere of internal affairs management in general, which have resulted in the processes of demilitarization, democratization and depolitization of police bodies ${ }^{19}$.

The strive to efficiency and quality assurance of the services provided to the public, improvement of their organization and distribution among the authorities is determined today as the strategic direction of police development in many countries of the world. In particular, at the Munich Congress in 1998, in defining the main approaches to construction of a new model of police activity, it has been emphasized that police should exist for citizens and therefore be regarded as a body providing services to citizens in a particular territory. Therefore, the service system needs further development ${ }^{20}$.

Based on the above provisions, the functioning of police structures in the developed countries of the world is associated with the provision of quality services to the population. Today, the state and its bodies, including internal affairs, are gradually turning into a service-oriented organization with a wide range of social services, given that the key to ensuring the effectiveness of their activity is the degree of satisfaction of

${ }^{18}$ Beyley D. 2001. Demokratizing the Police Abroad: What to Do and How to Do i3 Washington. British Delegation to the Czech Republic. 1991. 2nd Report. Sep. 1991. London. P. 13.

19 Легеза Є. Зарубіжний досвід правового регулювання адміністративних послуг, що надаються органами влади та його впровадження в діяльності міліції України. URL : http://radnuk.info/home/24281-2013-05-29-18-09-07.html.

${ }^{20}$ Toronto Police Services Organizatiohal Chart : approved by the Toronto Police Services Board on Feb. 21, 2008. Офіційний веб-сайт поліції Торонто, Канада. URL : http://www.torontopolice.on.ca/orgchart.pdf; Іншин M. I. Правове регулювання вивільнення працівників органів внутрішніх справ України : навчально-практичний посібник / За ред. В. С. Венедиктова. Харків : Ун-т внутр. справ, 2000. 159 с. 
civil society actors. This necessitates the search for new concepts and models of policing and requires a study of police service provision in the light of changes in the service market ${ }^{21}$.

Law enforcement agencies in most countries of the world are actively using the Community Policing model, which combines dual crime fighting with police structures and members of the public. Community Policing, in fact, has become the new philosophy of policing, according to which the police are formed in accordance with the principle of decentralization of its structure, acting on a proactive basis in close cooperation with citizens, jointly identifying problems and solving them ${ }^{22}$. According to this model, there have been changes in the work with police personnel. Studies show that this concept increases police satisfaction with their work, positively changes the motivation of their work, expands the role of police officers in society, improves the relationship between the police officers themselves, and between police officers and civilians ${ }^{23}$.

In the Czech Republic, the main tasks of ensuring the performance of the service function, according to the Police Act adopted in 1991, are assigned to regional and municipal police, whose units are more flexible to local problems than national police. An example of organizational changes to the service of ordinary citizens by the police is the creation of a so-called "Complaint Table" at each police station ${ }^{24}$.

The London Police Department has the London Ambulance Service, The London Emergency Services Liaison Panel, providing free medical services to the public in the event of an accident or emergency, as well as transportation services to health facilities, providing special comfortable conditions for the seriously ill. At the same time, the administration worked on the development and improvement of service to the population in accordance with the Improvement Program for

${ }^{21}$ Кріцак І.В. Теоретико-правовий аналіз існуючих моделей функціонування поліції та проблема реалізації функції надання послуг населенню органами внутрішніх справ. Право і безпека. 2013. № 1 (48). С. 23-29.

${ }^{22}$ Hauer V. D. Police in Western Europe. Bonn, 1992.

23 Дегтярев Л. М. Максименко Н. П., Соловьева М. Г. Полиция буржуазных государств. М., 1966. С. 44; Бесчастний В. Міжнародний досвід у діяльності міліції України. Віче. 2009. № 24. URL: http://www.viche.info/journal/1780.

24 Окопник О. М. Органи внутрішніх справ в організаційно-правовому механізмі реалізації виконавчої влади в Україні : дис. ... канд. юрид. наук : 12.00.07. Харків, 2007. C. 78.; Organization of the Czech Republic police force. Офіційний вебсайт поліції Чехії. URL: http://www.czech.cz/en/czech-republic/security/securityforces/theczech-republic-police-force. 
2001-2006, which was aimed to achieve the level of service of world quality standards ${ }^{25}$.

The reform process in the mid-1990s in Canada was based on financial principles, resulting in a significant reduction in the number of public servants, including the Ministry of Public Works and Public Services, which led to a mass discussion of the quality of service provision in the country as a result of such activities. The reforms have resulted in the building of a new service provision system. The organizational structure of the Toronto Police Offices (Canada), approved on December 21, 2008, did not envisage separate service units, as the concept of "service" has a literal meaning - "serve" the people ${ }^{26}$. That is, the very functioning of the police was already regarded as the provision of law enforcement services. In this case, information, logistical and communication units act as business entities, in addition to servicing police units ${ }^{27}$.

Concerning the licensing system of police services, Georgia's experience is interesting. The Service Agency of the Georgia's Ministry of Internal Affairs operates in this country. It is a unit that provides any services related to vehicles, including customs clearance, acceptance of payments related thereto, expert review, state license plate production, driver's license and theoretical and practical examination for its issuance, issuing permits to purchase different types of weapons, registering and reissuing them, providing criminal records, fulfillment apostil functions, etc. ${ }^{28}$

25 Матюхіна Н. П. Поліція Великобританії: сучасні тенденції розвитку та управління : монографія ; за заг. ред. д-ра юрид. наук, проф. О. М. Бандурки. Харків : Консум, 2001. С. 56.

${ }^{26}$ Toronto Police Services Organizatiohal Chart : approved by the Toronto Police Services Board on Feb. 21, 2008. Офіційний веб-сайт поліції Торонто, Канада. URL: http://www.torontopolice.on.ca/orgchart.pdf.

27 Бандурка О. М. Міліція i населення: Теорія і досвід партнерства : монографія. Харків : Вид-во Нац. ун-ту внутр. справ, 2004. С. 57; Легеза Є. Зарубіжний досвід правового регулювання адміністративних послуг, що надаються органами влади та його впровадження в діяльності міліції України. URL: http://radnuk.info/home/24281-2013-05-29-18-09-07.html

${ }_{28}$ Service agency. Офіційний веб-сайт Міністерства внутрішніх справ Грузії. URL : http://police.ge/ge/lepl/momsakhurebis-saagento?sub=488; Україна ознайомилась 3 позитивним досвідом реформування ДАІ Грузії. - 30.11.2011. Офіційний портал Всеукраїнської спеціальної колегії з питань боротьби з корупцією та організованою злочинністю. URL : http://vsk.kiev.ua/index.php?option=com_k2\&view=item\&id=401: ukraina-oznaiomylas-z-pozytyvnym-dosvidom-reformuvannia-dai hruzii\&Itemid=192 \&lang=ua. 
For example, to obtain a permit to purchase a weapon, the following documents must be submitted to the Georgia Police Service: a statement; receipt for the purchase of weapons; ID card or residence permit, proof of residence; health certificate, approved by the Ministry of Labor, Health and Welfare of Georgia form. In addition, you must provide a document confirming the payment of the permit to purchase weapons and a receipt confirming the payment for service, in particular, it is a matter of registering a weapon. This permit can be issued within one business day. Thanks to the state-of-the-art computer system, there is no need to provide additional certificates, various kinds of certificates from other institutions to obtain any permit document, which makes it easier to issue the required document to the citizen ${ }^{29}$. The system is designed so that people do not spend much time on bureaucratic procedures. As a result, virtually all the queues have disappeared, although thousands of people are served at the Police Service Agency daily.

Thus, in Georgia, the provision of administrative services by the police is based on world standards, where a person acts as prime value and quality satisfaction of his needs is a top priority in the functions of public authorities. Therefore, Georgia's experience is an example for other post-Soviet countries, including Ukraine, in reforming the Ministry of Internal Affairs of Ukraine and organizing its activities to provide administrative services to the public.

Concluding, it should be noted that studying the best practices of organizing the provision of administrative services in foreign countries will enable to develop strategically important directions and specific means for reforming the area of providing such services to public authorities in Ukraine. It should be noted that the main areas of improvement of the organization of administrative services in developed countries were and remain: decentralization of the provision of administrative services through delegation of such powers to local authorities or private organizations on the basis of contractualcontractual form of relations with the latter "Denationalization of

${ }^{29}$ Мирошник Я. Подолання корупції в Грузії: висновки для України. URL : http://www.transparentukraine.org/?p=6931; Україна ознайомилась 3 позитивним досвідом реформування ДАІ Грузії. - 30.11.2011. Офіційний портал Всеукраїнської спеціальної колегії з питань боротьби з корупцією та організованою злочинністю. URL : http://vsk.kiev.ua/index.php?option=com_k2\&view=item\&id=401:ukrainaoznaiomylas-z-pozytyvnym-dosvidom-reformuvannia-dai hruzii\&Itemid=192\&lang=ua. 
services" (privatization, use of private sector methods in public institutions, etc.); creation of the most convenient and affordable conditions for obtaining services to consumers (in particular, the development of the idea of integrated offices - centers operating on a "one-stop-shop" principle); implementation of information technology for service provision. This applies both to the digitization of individual services and to the creation of public service portals (eg, www.servicepublic.fr (France), www.servicecanada.gc.ca (Canada)); defining the list of administrative services through monitoring the opinions of consumers, i.e. citizens; establishing partnerships between the state and its population, where the citizen is a customer (consumer) and the state, through authorized bodies, acts as a service element in meeting its needs; clear control over the quality of the services provided and determination of the level of satisfaction of citizens with receiving it; introducing sound decision-making procedures that minimize the conditions for corruption and abuse.

In addition, analyzing the experience of foreign countries in the field of administrative services, we support the proposal of V.B. Averyanov and I.O. Dragan, which is the need to adopt the Administrative Procedure Code. This position is justified by the fact that this regulatory act should regulate the general procedure for the provision of administrative services, starting with the rules on registration of the request for service and ending with the procedure for appealing the decisions of the authorities. Problems with the organization of the provision of administrative services require further elaboration and legislative regulation in Ukraine on a uniform methodological basis ${ }^{30}$.

It is also an important mission of our legislation to support supervision over bodies that will meet the needs of citizens by providing them with appropriate services. The Netherlands experience, where an ombudsman institution operates and regulates and monitors the performance of their duties, may be helpful ${ }^{31}$.

${ }^{30}$ Авер'янов В. Б. Виконавча влада і адміністративне право. Кb]s : Видавничий Дім «Ін-Юре», 2002. С. 356; Драган I. О. Організація надання публічних послуг населенню органами влади: зарубіжні практики. Державне управління: удосконалення $i$ розвиток. 2014. № 4. URL : http://www.dy.nayka.com.ua/ ?ор $=1 \& \mathrm{z}=703$.

${ }^{31}$ Тищенкова I. O. Європейський досвід захисту прав громадян у сфері надання адміністративних послуг та напрями його впровадження в Україні. Науковий вісник Дніпропетровського державного університету внутрішніх справ. 2013. № 3. С. 249. 
In Ukraine, it is necessary to continue the practice of opening centers for providing administrative services to the population. When you create them, you should consider the number of clients they will serve, which has not yet been done. For example, the Berlin Universities of Services are created at the rate of fifty-sixty thousand inhabitants, which ultimately affects the number of staff and the quality of the services provided. It is also advisable in Ukraine to set up mobile administrative service centers that will operate in remote settlements.

Also, in the process of work of department stores, we propose to use as much as possible the capabilities of modern information technologies - electronic queue management system, formation of unified databases of access, use of opportunities of remote access to information, application for a permit or license by e-mail, etc. This will reduce the time required to obtain the required service and generally improve the quality of the latter ${ }^{32}$.

In the context of reforming the Ministry of Internal Affairs of Ukraine and the activities of the National Police as a public service entity, the foreign experience in this matter should also be taken into account. Today, police officers need to perceive citizens not only as partners but also as their clients. And, accordingly, to plan the work in such a way that the law-abiding citizens do not receive any complaints about the quality of police service. The main task of the police at the present stage in Ukraine should be to serve first of all the society, the citizens, and then the state and the government. In this context, it is positive that the Law of Ukraine "On the National Police" came into force 7 November 2015 reflects in its provisions the global trends in the designation and functioning of such a body. Namely, such provisions are that the National Police is defined by the central body of executive power, which serves the society through the fulfillment of its tasks, which is the provision of police services in various spheres of society ${ }^{33}$.

We should note that in the fulfillment of their administrative service tasks, the newly formed police force should establish links with the Administrative Services Centers, in addition to delegate to the latter

32 Жарая С. Б. Досвід надання адміністративних послуг у зарубіжних системах державного управління. Науковий вісник Академії муніципального управління. Серія: Управління. 2010. Вип. 1. С. 69.

33 Про Національну поліцію : Закон України від 2 липня 2015 р. № 580-VIII URL : http://zakon5.rada.gov.ua/laws/show/580-19. 
some powers that are within their competence. Using foreign experience, in particular regarding the list of administrative services provided by the universities of services, we support the proposals of experts of the Center for Political and Legal Reforms, who, having examined the bill No. 2567 "On Service Services and Service Centers of the Ministry of Internal Affairs of Ukraine" ${ }^{34}$, consider that he contravenes the Law on Administrative Services and is subject to rejection. In addition, experts believe that most of the services provided by the Ministry of Internal Affairs of Ukraine are appropriate to transfer to local governments, as it is practiced in the leading European countries. In particular, when issuing a driver's license, you must refuse to take the exam again at the MIA's territorial service centers. That is, the exam must be passed once in a driving school. The Ministry of Internal Affairs still has the responsibility for accrediting driving schools. Then it would be much easier to issue and exchange a certificate ${ }^{35}$. This authority should be delegated to local governments, which will have significant benefits. First of all, providing the service will be as convenient as possible for consumers. It will be available through the Administrative Services Centers. These centers are designed to make the process of obtaining administrative services as fast, comfortable and affordable as possible. The citizen should come to the center and provide the administrator with documents. In this case, by analogy with foreign experience, the following are: passport or document replacing it (for presentation only); Certificate of completion of the driver training facility; two color photo cards $3,5 \times 4,5 \mathrm{~cm}$ in size; medical certificate of the established sample; receipt for payment of administrative service. The driver's license can be issued on the day of the application: the work hours of the centers are flexible, and the driver's licenses themselves in large centers can be produced on the spot.

Second, citizens will be able to leverage the quality of this service. Yes, everyone will be able to demand from the mayor and deputies

34 Про сервісні послуги та сервісні центри Міністерства внутрішніх справ України : Проект Закону України від 2 квітня 2015 p. № 2567. URL : http://w1.c1.rada.gov.ua/pls/zweb2/webproc4_1?pf3511=54676.

${ }^{35}$ Реформа МВС: ще більше довідок, платних послуг і ніякої децентралізації. 15.04.2015 // UAinfo. URL : http://uainfo.org/blognews/528527-reforma-mvs-sche-blshedovdok-platnih-poclug-nyakoyi-decentralzacyi.htm 
transparent and comfortable conditions of its provision, while influence on the central level bodies is minimal ${ }^{36}$.

In addition, there is no need to rush into the introduction of "chip" driver's license, because objectively Ukraine does not need it in the coming years. In this case, the certificate can be issued within one to two days, because it can be produced locally.

In the procedure of registration of vehicles it is necessary to refuse expert examination of vehicles and paid invoices. This administrative service would then be significantly faster and cheaper for citizens. You should also refuse a service such as "issuing a certificate of no (criminal record)". Here, the state should develop a different mechanism for providing relevant information at the request of the authorities, and not make money from such certificates ${ }^{37}$.

But taking into account the designation of the structural units of the Ministry of Internal Affairs of Ukraine and the specifics of their functioning, it is clear that not all administrative services of the Ministry of Internal Affairs can and should not be delegated to local governments at all. In particular, these are the ones that relate to the permit system, because this area is most closely linked to the life and health of citizens. And this, as we know from the provisions of the Constitution of Ukraine, is of the greatest value to the state. However, it seems appropriate to separate administrative powers from other police functions, in particular by operating within the structure of the MIA of a special unit (following the example of Georgia), which should provide a full list of administrative services to citizens within their competence. The activities of such a unit should be based on the principle of "single window". For this purpose, the Ministry of Internal Affairs of Ukraine should develop quality standards in the provision of administrative services, which will include standards of professional action of the Ministry of Internal Affairs personnel in providing such services, as well as clear and understandable mechanisms for ensuring the quality of administrative services. In addition, the list of services and fees that may be provided by such units should be clearly defined.

${ }^{36}$ Школьный Е. Зачем платить дважды? Украйнська правда: Экономическая правда. 02.07.2014. URL : http://www.epravda.com.ua/rus/columns/2014/07/2/472530.

37 Тимощук В. Реформа MBC: ще більше довідок, платних послуг та ніякої децентралізації / В. Тимощук. URL: http://pravo.org.ua/administratywni-posluhy/1918reforma-mvs-shche-bilshe-dovidok-platnykh-pocluh-i-niiakoi-detsentralizatsii.html. 
Today some steps have already been taken to regulate the relations related to the provision of services and their provision to individuals and legal entities. In particular, the previously drafted bill No. 2567 "On Services and Service Centers of the Ministry of Internal Affairs of Ukraine" 38 was developed, in which the service providers define the MIA service centers. The purpose of such a center is to meet the needs of individuals and legal entities in obtaining services, the introduction of modern technologies, improving the service and promoting the development of the system of the Ministry of Internal Affairs of Ukraine.

However, in our opinion, in Art. 10 "Types of services and fees for their provision" of the above draft law does not contain a complete list of administrative services related to the permit system and which may be provided by the Ministry of Internal Affairs service center. Therefore, we consider it necessary to amend this article with the following types of administrative services:

1) issuing permits for the acquisition and transportation of firearms, ammunition, and other items covered by the permit system for individuals and legal entities;

2) issuing a permit for storage and carrying (registration, reregistration): prize weapons, hunting, cold, pneumatic weapons, other items covered by the permit system;

3 ) re-registration of the weapon at the place of its registration from one owner to another;

4) issuance of permission (registration of documents) for the opening and operation of objects of the permit system, working with explosive materials, pyrotechnic workshops and other objects defined by the legislation of Ukraine;

5) issuance of a license:

- manufacturing and repair of non-military firearms and ammunition, cold weapons, air guns of caliber more than 4,5 millimeters and bullet speed of more than 100 meters per second, trade in nonmilitary firearms and ammunition, cold weapons caliber exceeding 4,5 millimeters and ball speed exceeding 100 meters per second;

38 Про сервісні послуги та сервісні центри Міністерства внутрішніх справ України : Проект Закону України від 2 квітня 2015 р. № 2567. URL : http://w1.c1.rada.gov.ua/pls/zweb2/webproc4_1?pf3511=54676. 
- for the production of special means charged with tear and irritant substances, personal protection, active defense and their sale;

- provision of services for protection of property and citizens;

- to carry out activities related to the manufacturing and sale of pyrotechnics ${ }^{39}$.

Therefore, these amendments will reflect at the legislative level the full range of administrative services, including in the field of police authorization, which will enable citizens to meet their needs by contacting the relevant MIA Service Center. By establishing such fullfledged and multifunctional centers, the Ministry of Internal Affairs will become closer to the task of transitioning from punitive to social-service content of police activity as a European-style body.

\section{CONCLUSIONS}

The current system of administrative service provision in most countries of the world has emerged from a long process of reform. The basis of such transformations was: 1) the formation of civil society on the basis of a market economy; 2) bringing the public authorities closer to the population by introducing changes in approaches to their functioning, namely the creation of a service department; 3) simplification of procedures for citizens to obtain appropriate services from public authorities; 4) widespread use of innovative technologies in the provision of administrative services; 5) implementation of quality criteria for compliance of services provided to the public by public authorities. In addition, today, the general tendency to provide administrative services to the public is to create service centers that act as "one-stop shops" of services. Such centers are usually set up by municipal authorities and address the pressing needs of the community concerned.

Regarding the foreign experience in providing administrative services by law enforcement agencies, the National Police of Ukraine should act as a public authority service whose task should be to provide high quality administrative services to citizens. Such services should be provided by specialized MIA service centers with a wide range of

39 Про затвердження переліку платних послуг, які надаються підрозділами Міністерства внутрішніх справ, Національної поліції та Державної міграційної служби, і розміру плати за їх надання : Постанова Кабінету Міністрів України від 4 червня 2007 р. № 795. URL : http://zakon4.rada.gov.ua/laws/show/795-2007-\%D0\%BF. 
administrative services. The service system itself needs further development on the basis of consumer (citizen) orientation, accessibility, confidentiality, simplification of procedures for obtaining such services, efficiency and effectiveness.

At the present stage of reforming the Ministry of Internal Affairs of Ukraine, one should take into account global trends in the organization and provision of services to the population, which is based on the creation of service centers, which act as "universities of services" with a "single window" system. Positive is the creation of service centers of the Ministry of Internal Affairs, which should become in the near future the focus of the whole range of administrative services, which were once provided by various structural units of law enforcement agencies, including units of the licensing system, and are now implemented by the National Police of Ukraine. In this regard, the list of administrative services of police authorities needs to be expanded and legislatively defined. In addition, the provision of such services by the National Police of Ukraine should be aimed at meeting the needs of the consumer as quickly and as qualitatively as possible, that is, first and foremost, the realization of constitutional rights and freedoms of man and citizen. Such an approach as a whole will be one of the steps towards the implementation of the human-centric concept in the process of constructing a qualitatively new social development of the Ukrainian state, where the person and his good, not the immediate good of the state, are the basis and guide for the functioning of the whole state mechanism.

\section{SUMMARY}

The author has studied peculiarities of scientific genesis of the concept and the essence of administrative services provided by the National Police of Ukraine. He has analyzed the experience of some countries in this field.

The directions of improvement of the legal basis for the provision of administrative services in the field of permitting system of the National Police of Ukraine have been offered. In particular, in the process of reforming the Ministry of Internal Affairs of Ukraine it is necessary to use and build on foreign experience. At the same time there is a need to adopt a legislative normative act, which should ensure legal 
regulation of legal relations, in particular, in the sphere of arms trafficking.

In the author's opinion the list of administrative services of police authorities needs to be expanded and legislatively defined. In addition, the provision of such services by the National Police of Ukraine should be aimed at meeting the needs of the consumer as quickly and as qualitatively as possible.

\section{REFERENCES}

1. Авер'янов В.Б. Виконавча влада і адміністративне право. Київ : Видавничий Дім «Ін-Юре», 2002. 668 с.

2. Бандурка О.М. Міліція і населення: Теорія і досвід партнерства : монографія. Харків : Вид-во Нац. ун-ту внутр. справ, 2004. 199 c.

3. Бесчастний В. Міжнародний досвід у діяльності міліції України. Віче. 2009. № 24. URL: http://www.viche.info/journal/1780.

4. Дегтярев Л.М. Максименко Н. П., Соловьева М. Г. Полиция буржуазных государств. М., 1966. 142 с.

5. Денисюк Д.С. Визначення адміністративної послуги в діяльності органів внутрішніх справ. Актуальні проблеми державного управління. 2008. № 2. С. 401-405.

6. Драган I.О. Організація надання публічних послуг населенню органами влади: зарубіжні практики. Державне управління: удосконалення $i$ розвиток. 2014. № 4. URL : http://www.dy.nayka.com.ua/?op=1\&z=703.

7. Еропкин М.И. Управление в области охраны общественного порядка. М. : Юр. лит., 1965. 215 с.

8. Жарая С. Б. Досвід надання адміністративних послуг у зарубіжних системах державного управління. Науковий вісник Академії муніципального управління. Серія : Управління. 2010. Вип. 1. C. 64-70. C. 69.

9. Іншин М.I. Правове регулювання вивільнення працівників органів внутрішніх справ України : навчально-практичний посібник ; за ред. В.С. Венедиктова. Харків : Ун-т внутр. справ, 2000. $159 \mathrm{c}$.

10. Колонтаевский Ф.Е. Обеспечение социалистической законности в административной деятельности милиции : автореф. дис.. ...канд. юрид. наук : 12.00.07. М., 1970. 15 с. 
11. Кріцак І.В. Теоретико-правовий аналіз існуючих моделей функціонування поліції та проблема реалізації функції надання послуг населенню органами внутрішніх справ. Право $i$ безпека. 2013. № 1 (48). C. 23-29.

12. Легеза Є. Зарубіжний досвід правового регулювання адміністративних послуг, що надаються органами влади та його впровадження в діяльності міліції України. URL : http://radnuk.info/home/24281-2013-05-29-18-09-07.html.

13. Матюхіна Н.П. Поліція Великобританії: сучасні тенденції розвитку та управління : монографія ; за заг. ред. д-ра юрид. наук, проф. О. М. Бандурки. Харків : Консум, 2001. 131 с.

14. Мирошник Я. Подолання корупції в Грузії: висновки для України. URL : http://www.transparentukraine.org/?p=6931.

15. Окопник О.М. Органи внутрішніх справ в організаційноправовому механізмі реалізації виконавчої влади в Україні : дис. ... канд. юрид. наук : 12.00.07. Харків, 2007. 179 с.

16. Про адміністративні послуги : Закон України від 6 вересня 2012 р. № 5203-VI. Відомості Верховної Ради Украӥни. 2013. № 32. Ст. 409.

17. Про затвердження переліку платних послуг, які надаються підрозділами Міністерства внутрішніх справ, Національної поліції та Державної міграційної служби, і розміру плати за їх надання : Постанова Кабінету Міністрів України від 4 червня 2007 р. № 795. URL : http://zakon4.rada.gov.ua/laws/show/795-2007-\%D0\%BF.

18. Про затвердження Положення про Міністерство внутрішніх справ України : Указ Президента України від 06 квітня 2011 р. № 383. URL : http://zakon3.rada.gov.ua/laws/show/383/2011.

19. Про заходи щодо впровадження Концепції адміністративної реформи в Україні : Указ Президента України від 22 липня 1998 р. № 810. Офіиійний вісник Украӥни. 1999. № 21. С. 32.

20. Про заходи щодо упорядкування адміністративних послуг : Постанова Кабінету Міністрів України від 17 липня 2009 р. № 737. URL : http://zakon5.rada.gov.ua/laws/show/737-2009-\%D0\%BF.

21. Про Національну поліцію : Закон України від 2 липня 2015 p. № 580-VIII URL : http://zakon5.rada.gov.ua/laws/show/580-19.

22. Про основні напрямки конкурентної політики на 2002 2004 pp. : Указ Президента України від 19 листопада 2001 р. № 1097/2001. Офіиіийний вісник Украӥни. 2001. № 47. С. 14. Ст. 2056. 
23. Про сервісні послуги та сервісні центри Міністерства внутрішніх справ України : Проект Закону України від 2 квітня 2015 p. № 2567. URL : http://w1.c1.rada.gov.ua/pls/zweb2/ webproc4_1?pf3511=54676.

24. Ратушняк В. Перспективні шляхи удосконалення управління міліцією громадської безпеки в Україні. Вісник Київського начіонального університету імені Тараса Шевченка. Серія: Юридичні науки. 2013. № 2 (96). С. 12-16.

25. Реформа МВС: ще більше довідок, платних послуг і ніякої децентралізації. - 15.04.2015 // UAinfo. URL : http://uainfo.org/ blognews/528527-reforma-mvs-sche-blshe-dovdok-platnih-poclugnyakoyi-decentralzacyi.htm.

26. Сєніна А.О. Особливості та організаційний досвід надання адміністративних послуг у країнах ЄС. Бізнес Інформ. 2014. № 8. C. 25-33.

27. Советское административное право / под ред. А.Е. Лунева. М. : ВЮЗИ, 1960. 442 c.

28. Суббот А. Застосування в Україні передових світових стандартів організації ефективної діяльності правоохоронних органів. Віче. 2014. № 10. С. 5-8. С. 7.

29. Тимощук В. Реформа MBC: ще більше довідок, платних послуг та ніякої децентралізації / B. Тимощук. URL: http://pravo.org.ua/administratywni-posluhy/1918-reforma-mvs-shchebilshe-dovidok-platnykh-pocluh-i-niiakoi-detsentralizatsii.html.

30. Тимощук В.П. Адміністративні послуги: проблеми теорії, законодавства i практики в Україні. Адміністративне право $i$ проиес. 2014. № 3(9). C. 104-120. URL: http://applaw.knu.ua/ index.php/arkhiv-nomeriv/3-9-2014-jubilee/item/383-administratyvniposluhy-problemy-teoriyi-zakonodavstva-i-praktyky-v-ukrayinitymoshchuk-v-p.

31. Тищенкова I.О. Європейський досвід захисту прав громадян у сфері надання адміністративних послуг та напрями його впровадження в Україні. Науковий вісник Дніпропетровського державного університету внутрішніх справ. 2013. № 3. С. 245-251.

32. Україна ознайомилась 3 позитивним досвідом реформування ДАІ Грузії. - 30.11.2011. Офіційний портал Всеукраїнської спеціальної колегії з питань боротьби з корупцією та організованою злочинністю. URL : http://vsk.kiev.ua/index.php?option=com_k2\& 
view=item\&id=401:ukraina-oznaiomylas-z-pozytyvnym-dosvidom-refor muvannia-dai hruzii\&Itemid=192\&lang=ua.

33. Шапоренко М.М. Адміністративні послуги правоохоронних органів: до проблеми понятійного апарату. Право і суспільство. 2011. № 5. C. 118-123.

34. Школьный Е. Зачем платить дважды? Українська правда: Экономическая правда. 02.07.2014. URL http://www.epravda.com.ua/rus/columns/2014/07/2/472530.

35. Beyley D. 2001. Demokratizing the Police Abroad: What to Do and How to Do i3 Washington. British Delegation to the Czech Republic. 1991. 2nd Report. Sep. 1991. London. P. 13.

36. Hauer V. D. Police in Western Europe. Bonn, 1992.

37. Organization of the Czech Republic police force. Офіційний веб-сайт поліції Чехії. URL: http://www.czech.cz/en/czechrepublic/security/security-forces/theczech-republic-police-force.

38. Service agency. Офіційний веб-сайт Міністерства внутрішніх справ Грузії. URL : http://police.ge/ge/lepl/momsakhurebissaagento?sub $=488$.

39. Toronto Police Services Organizatiohal Chart : approved by the Toronto Police Services Board on Feb. 21, 2008. Офіційний веб-сайт поліції Торонто, Канада. URL: http://www.torontopolice.on.ca/ orgchart.pdf.

Information about the author: Fomenko A. Ye. $\mathrm{PhD}$, Deserved Lawyer of Ukraine, Rector, Dnipropetrovsk State University of Internal Affairs 26, Gagarina av., Dnipro, 49005, Ukraine 